\title{
ПРО ПОДАЛЬШЕ УДОСКОНАЛЕННЯ СЕМЕСТРОВИХ КОМПЛЕКСНИХ ТЕСТОВИХ ІСПИТІВ У ТЕРНОПЛЬСЬКОМУ ДЕРЖАВНОМУ МЕДИЧНОМУ УНІВЕРСИТЕТІ ІМЕНІ І. Я. ГОРБАЧЕВСЬКОГО
}

\author{
Л. Я. Ковальчук, І. Р. Мисула, К. О. Пашко, П. Р. Сельський \\ Тернопільський державний медичний університет імені І. Я. Горбачевського
}

\section{ON FURTHER IMPROVEMENT OF COMPLEX SEMESTER TEST EXAMS IN THE TERNOPIL STATE MEDICAL UNIVERSITY BY I. YA. HORBACHEVSKY}

\author{
L. Ya. Kovalchuk, I. R. Mysula, K. O. Pashko, P. R. Selskyi \\ Ternopil State Medical University by I. Ya. Horbachevsky
}

\begin{abstract}
Семестрові комплексні тестові іспити визнано однією з найбільш об’ єктивних форм контролю рівня знань студентів, що позбавлена впливу суб' сктивного (людського) чинника. Але наші навчальні плани організації навчального процесу за кредитно-модульною системою мають значно більшу кількість навчальних модулів. Винесення тестових завдань зі всіх модулів одночасно на семестровий комплексний тестовий іспит розтягує його в часі та спричиняс збільшення навантаження на студентів, тому доцільним є поділ семестрового комплексного тестового іспиту на дві частини. Збілышення бази до п'ятисот тисяч тестових завдань, ситуаційних задач та рисунків не дозволяє зазубрювати відповіді, а вимагає щоденно наполегливо засвоювати та глибоко розуміти суть теоретичного матеріалу, а також освоювати на високому рівні практичні навички, які лежать в основі вирішення ситуаційних задач та розпізнавання рисунків.
\end{abstract}

Complex semester test exams are rightfully considered to be one of the most objective forms of the level of students' knowledge monitoring that is deprived of the influence of subjective human factor. The curriculum of the educational process for creditmodular system includes a rather great number of training modules. Taking-up tests on all modules at once at the semester test exam stretches it in time and increases the workload on students, so it is reasonable to divide the exam into two parts. In order to avoid the mechanical learning of tests their quantity in the base was increased up to five hundred thousands, including situational problems and tests to figures. It makes it impossible for the students to drill the answers, but requires their everyday work, profound understanding of the theoretical material and developing of high level of practical skills.

Вступ. Вперше серед усіх ВМ(Ф)НЗ України в нашому університеті вирішена проблема об'єктивності підсумкового контролю знань студентів, що практично усунула суб’'єктивні аспекти екзаменів, дозволила оцінювати знання незалежно від людського фактора, тобто уподобань, настрою екзаменатора та інших чинників, які впливають на оцінку знань студентів, шляхом проведення семестрового комплексного тестового (лише тести дають змогу досягнути вищого ступеня об’ єктивності) іспиту для студентів усіх факультетів та курсів [1]. Саме об' єктивна та незалежна система оцінювання знань студентів, що передбачає "послідовне використання оприлюднених критеріїв, правил і процедур”, $є$ одним із семи Європейських стандартів і рекомендацій щодо внутрішнього забезпечення якості у вищих навчальних закладах, розроблених Свропейською асоціацією із забезпечення якості вищої освіти. Відповідно до даних стандартів та рекомендацій, “очікується, що процедури оцінювання студентів матимугь чіткі й оприлюднені критерії виставлення оцінок; не покладатимуться на судження лише одного екзаменатора". Семестрові комплексні тестові іспити є нормою в університетах Європи і визнані однією з найбільш об'єктивних форм контролю рівня знань студентів, що позбавлена впливу суб'єктивного (людського) чинника [2]. Вони органічно ввійшли у навчальний процес нашого університету і визнані професорськовикладацьким складом та студентами. Про його об'єктивність свідчить те, що в більшості випадків оцінки, які отримують студенти на іспиті, мають незначні відхилення від оцінок поточної успішності, а відповідно, практично немає і апеляцій з боку студентів [3]. А там, де на об'єктивність оцінки знань не впливає суб' єктивний чинник, немає і грунту для корупції, що стає вагомим чинником припливу на навчання в наш університет як вітчизняних, так і зарубіжних студентів.

() Л. Я. Ковальчук, І. Р. Мисула, К. О. Пашко, П. Р. Сельський 
Основна частина. Наші навчальні плани організації навчального процесу за кредитно-модульною системою, на відміну від навчальних планів аналогічних університетів Європи, мають значно більшу кількість навчальних модулів. Відповідно, це спричиняє збільшення навантаження на студентів під час складання семестрових комплексних тестових іспитів та розтягує їх тривалість. Надмірне навантаження не дає можливості студентам повною мірою показати свій рівень знань, а тривалий термін складання іспиту призводить до значної розумової втоми. Тому до початку зимової екзаменаційної сесії 2010-2011 н. р. питання щодо вдосконалення складання семестрових комплексних тестових іспитів було спочатку винесено на розгляд вченої ради університету. В його обговоренні взяли активну участь, поряд 3 професорами та доцентами, і студенти, які теж є членами вченої ради. Кожен бажаючий висловив свою думку, особливо уважно було вислухано та взято до уваги пропозиції студентів, тому що вони $є$ безпосередніми учасниками цього процесу $\mathrm{i}$ бачать його зсередини, а крім того, організація іспиту впливає на їх успішність.

Результатом обговорення питання щодо вдосконалення проведення семестрових комплексних тестових іспитів стало одностайно прийняте членами вченої ради рішення про те, щоб під час кожного іспиту студенти складали не більше восьми модулів. Відповідно, більшість іспитів були поділені навчально-науковим відділом незалежного тестування знань студентів на дві частини. Це дозволило скоротити час проведення іспиту до чотирьох годин і менше. Після двох годин іспиту екзаменаційна комісія оголошувала студентам перерву на 20 хв. Методично порядок складання іспиту залишився попереднім. Студентам надавали по три дні на підготовку до складання кожної частини семестрового комплексного тестового іспиту. Треба зауважити, що розклад складання іспитів взимку розрахований так, щоб студенти всіх курсів та факультетів завершили сесію не пізніше 30 грудня і встигли на святкування Нового року. Ті ж студенти, які склали іспит на незадовільні оцінки, були вимушені перескладати його після зимових свят, що, без сумніву, позбавило їх повноцінної радості від святкування Нового року та Різдва Христового. Тому це додатково стимулюватиме студентів до систематичного навчання протягом навчального періоду, без марного сподівання, що вони встигнуть вивчити весь навчальний матеріал за декілька днів підготовки до першої та другої частин іспиту.

Для повного переконання у правильності прийнятого рішення щодо поділу семестрового комплексного тестового іспиту на дві частини після зимової екзаменаційної сесії, згідно з наказом ректора університету від 19.01. 2011 р. № 32, було проведено всеуніверситетський референдум студентів про його доцільність. Організацією референдуму займалася спеціально створена комісія, в компетенції якої були лише розробка і затвердження графіка проведення референдуму в лекційні дні, форми та змісту бюлетенів для таємного голосування і схеми протоколу лічильної комісії. Студенти всіх факультетів самі проводили референдум у лекційній аудиторії, для чого кожного разу вибирали лічильну комісію, яка за результатами таємного голосування заповнювала протоколи засідання та відразу ж оголошувала в аудиторії результати голосування. У підсумку 87,7 \% студентів університету підтримали поділ семестрового комплексного тестового іспиту на дві частини. Результати референдуму були обговорені та затверджені вченою радою університету 08.02.2011р. (протокол № 9) та студентською радою університету 09.02.2011 р. (протокол № 137). Одностайно обидві ради вирішили, що відтепер методика проведення у подальшому семестрового комплексного тестового іспиту полягатиме в його поділі на дві частини. Усі ці дані було висвітлено у газеті “Медична академія".

Крім того, база тестових завдань 3 кожної дисципліни 3 кожним семестром стає все більшою та урізноманітнюється за рахунок ситуаційних задач та рисунків, які кожен студент отримує перед складанням іспиту у вигляді виданих друкарським способом збірників окремо для кожного курсу. Навчально-науковий відділ незалежного тестування знань студентів після кожної екзаменаційної сесії проводить аналіз тестових завдань 3 метою визначення їх валідності, отримані дані доводяться до відома кафедр для усунення виявлених недоліків. Тепер вже база досягає п'ятисот тисяч тестових завдань, ситуаційних задач та рисунків, що нанівець зводить всі спроби скласти тестовий іспит методом зазубрювання відповідей. Забезпечити позитивний результат може тільки щоденна наполеглива робота із засвоєння та глибокого розуміння суті теоретичного матеріалу, а також освоєння на високому рівні практичних навичок, які лежать в основі вирішення ситуаційних задач та розпізнавання рисунків.

Одним із показників ефективності проведення контролю знань шляхом складання семестрових комплексних тестових іспитів стало те, що кількість студентів медичного факультету, які не склали іспит "Крок 1" (що є централізованим державним контролем за якістю підготовки студентів) у 2010 р. 3 першого разу (чотири особи), значно менша порівняно 3 2009 р. (двадцять осіб). Хоча результати складання 